\title{
Nutrients status of soil as influenced by varied levels of sulphur and organic sources of soybean (Glycine max L.) in Alfisols of Karnataka
}

Sahebagouda, T. Chikkaramappa and P. K. Basavaraja

Received : 26.05.2019; Revised : 16.11.2019; Accepted : 28.11.2019

MEMBERS OF RESEARCH FORUM:

Corresponding author :

Sahebagouda, Department of Soil

Science and Agricultural Chemistry,

College of Agriculture, University of

Agricultural Sciences, GKVK,

Bengaluru (Karnataka) India

Email: agrisaheb@gmail.com

Co-authors :

T. Chikkaramappa and P. K. Basavaraja, Department of Soil Science and Agricultural Chemistry, College of Agriculture, University of Agricultural Sciences, GKVK, Bengaluru (Karnataka) India

\section{Summary}

A field experiment was conducted during Kharif 2016 to study the nutrients status of soil as influenced by varied levels of sulphur and organic sources of soybean (Glyasine max L.) in Alfisols of Karnataka at Palanahalli, Magaditaluk, Ramanagara district. The experiment comprised application of 50 per cent and 100 per cent of NPK fertilizers, varied levels of sulphur and sources of organics in combination with seventeen treatments replicated thrice with RCBD. The experimental results revealed that the application of $100 \%$ RDF + poultry manure at $6 \mathrm{t} \mathrm{ha}^{-1}$ and gypsum at $20 \mathrm{~kg} \mathrm{ha}^{-1}$ through gypsum $\left(\mathrm{T}_{8}\right)$ had shown significantly higher the major available nutrients such as nitrogen $\left(281.33 \mathrm{~kg} \mathrm{ha}^{-1}\right)$, phosphorus $(45.55 \mathrm{~kg}$ $\left.\mathrm{ha}^{-1}\right)$ and potassium $\left(295 \mathrm{~kg} \mathrm{ha}^{-1}\right)$ after the harvest of soybean. Whereas maximum available secondary and micronutrients were recorded in $\mathrm{T}_{9}$ which received $100 \% \mathrm{RDF}+$ poultry manure at $6 \mathrm{tha}^{-1}+$ sulphur $40 \mathrm{~kg} \mathrm{ha}^{-1}$ through gypsum and it was on par with treatment $\mathrm{T}_{8}$ which received $100 \% \mathrm{RDF}+$ poultry manure $6 \mathrm{t} \mathrm{ha}^{-1}+$ sulphur $20 \mathrm{~kg} \mathrm{ha}^{-1}$ through gypsum as compared to rest of the treatments.

Key words : Nutrients, Sulphur, Organic, Soybean, Alfisols

How to cite this article : Sahebagouda, Chikkaramappa, T. and Basavaraja, P. K. (2019). Nutrients status of soil as influenced by varied levels of sulphur and organic sources of soybean (Glycine max L.) in Alfisols of Karnataka. Asian J. Soil Sci., 14 (1\&2) : 79-86 : DOI : 10.15740/HAS/AJSS/14.1and2/7986. 